older Nikāyas-his reverence was profound. What he abhorred was an unscientific jumble-such as what had too long passed as Buddhism--of distinct and successive "strata"; what he sought always to achieve was the presentment of historical fact in its due sequence and in ordered relation to what stratigraphically preceded and succeeded it. Incidentally, he never shrank from combating, in the interests of what he deemed truth, established and powerful interests; against Sanskrit supremacy in a sphere not its own he argued as energetically as Gotama himself argued against the sacrificial Brahmins; he never lost an opportunity of attacking animism and "the soul-theory". But I do not think that, keen disputant as he was, he ever wrote a line for writing's sake or without the sincerest conviction; nor was he ever more gratified-as the true friend to historical research which he was-than when he could put his own materials, knowledge, and quick intelligence at the disposal of a fellow-worker. Though he never made the claim, he was entitled to claim (and what nobler claim can a scholar advance ?) - " Yam satthārā karaṇiyam sāvakānam hitesin̄̄ anukampakena anukampà் upādāya, katam vo tam mayā.

C.

\title{
M. Clermont-Ganneau
}

In M. Clermont-Ganneau the Society has lost one of the most brilliant of its honorary members. He was born in 1848 and from his boyhood devoted himself to Oriental studies. Encouraged by Renan, he entered the Diplomatic Service, and spent much of his life in Syria, Palestine, and Constantinople, thus acquiring a first-hand acquaintance with Oriental thought, languages, and antiquities, which was invaluable to him in his scientific work. He also became, and always remained, rather a man of the world, but he was at the same time an untiring worker. His first great achievement was in connexion with the discovery of the Moabite Stone, when 
he was little more than 20 years old. Twenty years later he was made membre de l'Institut and professor at the Collège de France, where he proved himself to be the foremost authority in the world on Semitic epigraphy. He possessed in the highest degree the specially French gifts of brilliant insight and exact reasoning, and these gave a distinction to all the varied work of his long career.

He was much broken by the death of his mother in 1916, at the age of 101, but he still maintained much of his old verve. Only last summer at the centenary of the Société Asiatique he seemed as vigorous as ever-full of interest in all that was being done and planning work for the future. His end must have come unexpectedly. In answer to a letter urging him to come to the centenary celebration of this Society, he wrote that he was not very well and spoke of des ennuis et des soucis. Within a week he died at the age of 75 , and he died young.

A. Cowley.

\section{Dr. G. Buchanan Gray}

By the death of Dr. G. Buchanan Gray, England loses one of its most distinguished Hebraists and Biblical scholars, and Oxford a valued member of its teaching staff. Dr. Gray's death took place on 2nd November, 1922, at a meeting of the Theological Board, not many minutes before he was to have delivered his address as President for the year to the Oxford Society of Historical Theology; the circumstances were, therefore, tragic, as he was in his 57 th year and appeared to be in good health.

He studied the Semitic languages at Oxford and Marburg, where he attended the courses of J. Wellhausen, and entered the Independent ministry in 1893 ; two years before he had been appointed tutor at Mansfield College, Oxford, where he was promoted to be Professor of Hebrew and Old Testament Exegesis in 1900, and he further held certain University appointments connected with these studies. His Studies in

JRAS. APRIL 1923. 